\title{
PENERAPAN TEKNOLOGI SINKRONISASI ESTRUS DAN ARTIFICIAL INSEMINATION DI KELOMPOK TERNAK DI KABUPATEN LAMONGAN
}

\author{
Nuril Badriyah ${ }^{1)}$, Qabilah Cita K.N.S ${ }^{2)}$ dan M. Fathul Amin ${ }^{3)}$ \\ 1) Program Studi Peternakan Fakultas Peternakan Universitas Islam Lamongan \\ 2) dan 3) Fakultas Peternakan Universitas Islam Lamongan. \\ JI.Veteran No.53.A Lamongan
}

\begin{abstract}
ABSTRAK
Khalayak sasaran kegiatan ini adalah Petani Peternak yang tergabung dalam organisasi mitra Kelompok pembibitan sapi potong "Berkah" dan kelompok studi IB di desa Jetis, kecamatan Lamongan, Kabupaten Lamongan. Metode pendekatan yang digunakan adalah : pemetaan potensi lokasi, penyuluhan berkerjasama dengan Dinas Peternakan dan Kesehatan Hewan Kabupaten Lamongan, penyediaan sarana yang dibutuhkan, pelatihan dan pendampingan teknologi sinkronisasi estrus dan artificial insemination. Teknologi sinkronisasi birahi adalah teknologi untuk meningkatkan litter size denga teknik super ovulasi yang didahului dengan gertak birahi (Estrus Synchonization) serta pada teknologi Kawin buatan (Artificial Insemination / Al) pada ternak merupakan salah satu upaya penerapan teknologi tepat guna yang merupakan pilihan utama untuk peningkatan populasi dan mutu genetik sapi. Melalui kegiatan Al, penyebaran bibit unggul ternak sapi dapat dilakukan dengan murah, mudah dan cepat, serta diharapkan dapat meningkatkan pendapatan para peternak. Hasil kegiatan menunjukkan bahwa teknologi teknologi sinkronisasi estrus dan artificial insemination sangat tepat guna dalam mengatasi permasalahan peternak sapi potong pada program pembibitan. Kegiatan penyuluhan, penyediaan sarana, pelatihan dan manajemen pengelolaan kegiatan di tingkat kelompok mitra berjalan cukup baik. Diperlukan program pendampingan lebih lanjut terhadap kegiatan kelompok mitra khususnya kegiatan keberlangsungan teknologi pada kelompok tani - ternak. Program penelitian juga perlu dilakukan untuk membantu penyelesaian masalah yang muncul serta inovasi teknologi yang diperlukan.
\end{abstract}

Kata Kunci : Sapi, sinkronisasi estrus dan artificial insemination.

\section{PENDAHULUAN}

Provinsi Jawa Timur merupakan salah satu sentra populasi ternak sapi di Indonesia. Data Statistik PKH (2016) menyebutkan bahwa populasi ternak sapi di Jawa Timur terus meningkat sejak tahun 2009 hingga 2016 mencapai lebih dari 1 juta ekor. Salah satu daerah pengembangan ternak Sapi adalah di Kabupaten Lamongan dengan populasi menurut data Dinas PKH Kabupaten Lamongan adalah sejumlah 46.000 ekor di tahun 2016.

Desa Jetis Kecamatan Lamongan Kabupaten Lamongan merupakan salah satu desa yang masyarakatnya banyak bermata pencaharian sebagai petani dan peternak. Data monografi desa Jetis (2016) menunjukkan bahwa populasi penduduk berjumlah 1.266 orang. Penduduk yang mempunyai mata pencaharian dibidang pertanian sebanyak $211 \mathrm{KK}$. Luas lahan pertanian mencapai 148 hektar dimana 60\% nya adalah sawah berpengairan semi teknis untuk 2 kali tanam padi.

Secara umum kondisi usaha budidaya ternak Sapi di desa Jetis dikelola secara tradisional. Banyak permasalahan yang ada diantaranya : Kompetensi produksi ternak sapi milik peternak yang masih kurang, sistem perkandangan yang belum layak standar, belum menggunakan bibit unggul, dan manajemen reproduksi yang masih tradisional. Permasalahan tersebut menjadikan peternak cenderung merugi karena produktivitas ternak yang tidak bisa tinggi.

Perkembangan populasi ternak sapi di kelompok pembibitan sapi potong "Berkah" sejak tahun 2015 hingga kini tercatat 10 ekor yang dikandangkan dalam kandang komunal. Berdasarkan litter size ternak sapi idealnya dalam jangka waktu 3 tahun tersebut telah berkembang 1,5 kali lipat (Parwati, 2003). Faktor yang menyebabkan kurang berkembangnya ternak sapi di kelompok mitra ini adalah pelaksanaan manajemen 
reproduksi yang masih belum optimal.

Sejauh ini sudah dilakukan kawin buatan dengan petugas IB setempat dengan jenis sapi Peranakan Ongole (PO). Namun demikian, tingkat keberhasilan masih sangat rendah. Hal ini disebabkan beberapa faktor diantaranya : 1) kesalahan anggota kelompok dalam mendeteksi (menentukan) waktu birahi yang tepat dalam kandang komunal, 2) kondisi hormonal sapi indukan (akseptor) yang akan di kawin tidak memenuhi syarat, 3) teknik IB yang dilakukan kurang tepat, 4) nutrisi pakan yang tidak mencukupi 5) gangguan organ reproduksi sapi.

\section{METODE PELAKSANAAN}

\section{Lokasi dan Waktu}

Kegiatan ini dilaksanakan di kelompok Mitra yaitu : 1) Kelompok pembibitan sapi potong "Berkah" yang beralamat di Desa Jetis Kecamatan Lamongan Kabupaten Lamongan. Dan "kelompok studi IB" Fakultas Peternakan. Dilaksanakan pada tanggal 13 April sampai dengan 2 Agustus 2018.

\section{Metode Pendekatan}

Berdasarkan kondisi dan prioritas masalah yang ada maka perlu dilakukan penyelesaian masalah melalui beberapa metode pendekatan diantaranya: 1).Pemetaan kondisi teknis pengelolaan manajemen pembibitan sapi lokal di desa
Jetis kecamatan Lamongan kabupaten Lamongan. 2). Penyuluhan tentang teknologi Al jenis sapi limousin dengan sinkronisasi estrus Kerja sama dengan Dinas Peternakan dan Kesehatan Hewan Kabupaten lamongan 3). Pelatihan teknik mendeteksi birahi (estrus) ternak sapi lokal kepada anggota Kelompok Mitra.4). Pelatihan teknik Kawin Buatan (Artificial Insemination / Al) sapi pada kader di kelompok mitra.5). Pelatihan teknik sinkronisasi estrus pada kader di kelompok mitra.6). Penyediaan peralatan teknologi Al dan teknologi sinkronisasi di kelompok mitra. 7). Penyediaan tempat pelayanan Al sapi potong yang dikelola oleh kelompok mitra. 8). Pendampingan (bimbingan teknis) tentang keberlanjutan penerapan teknologi Al dengan sinkronisasi estrus pada sapi lokal di tingkat kelompok Mitra.

\section{HASIL DAN PEMBAHASAN}

\section{Hasil Persiapan Kegiatan}

Hal pertama yang dilakukan dalam kegiatan ini adalah pelatihan rencana kegiatan kepada anggota kelompok mitra dalam hal ini adalah Kelompok pembibitan sapi "Berkah" dan Kelompok Studi Inseminasi Buatan. Kegiatan yang telah dilakukan tersebut terlihat pada gambar 1 .

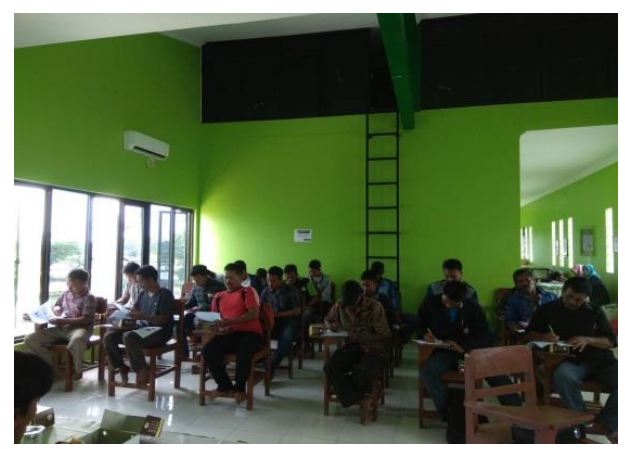

\section{Gambar 1. Sosialisasi Kelompok Pembibitan Sapi Potong “Berkah” dan Kelompok Studi} "IB"

Kegiatan sosialisasi ini dihadiri 20 peserta yaitu Kelompok Pembibitan Sapi Potong "Berkah" dan Kelompok Studi "IB" yang dilakukan di UPT. Agri Science Technopark Universitas Islam Lamongan. Semua yang hadir tersebur mempunyai kriteria yang telah ditentukan yaitu kepemilikan ternak dan lama berternak. Kegiatan ini mampu menjelaskan secara detail permasalahan, tujuan, bentuk kegiatan dan menyepakati jadwal kegiatan serta hal- hal yang harus disiapkan untuk kegiatan yang akan dilaksanakan nanti. Kegiatan dapat berjalan dengan baik dan terkoordinasi, sangat diperlukan adanya perencanaan untuk mencapai hasil yang diinginkan. Perencanaan adalah proses memilih sejumlah kegiatan untuk ditetapkan sebagai keputusan tentang suatu pekerjaan yang harus dilakukan, kapan, bagaimana dan siapa yang melakukannya (Nawawi, 2003). 
Kegiatan penyuluhan diadakan dua pertemuan. Penyuluhan dilakukan sebelum dilakukan kegiatan teknis di lapangan untuk memberikan pengetahuan secara teoritis kepada kelompok ternak sebagai bekal untuk diterapkan praktek di lapangan. Hasil kegiatan penyuluhan I kepada kelompok ternak seperti terlihat pada gambar 2 .

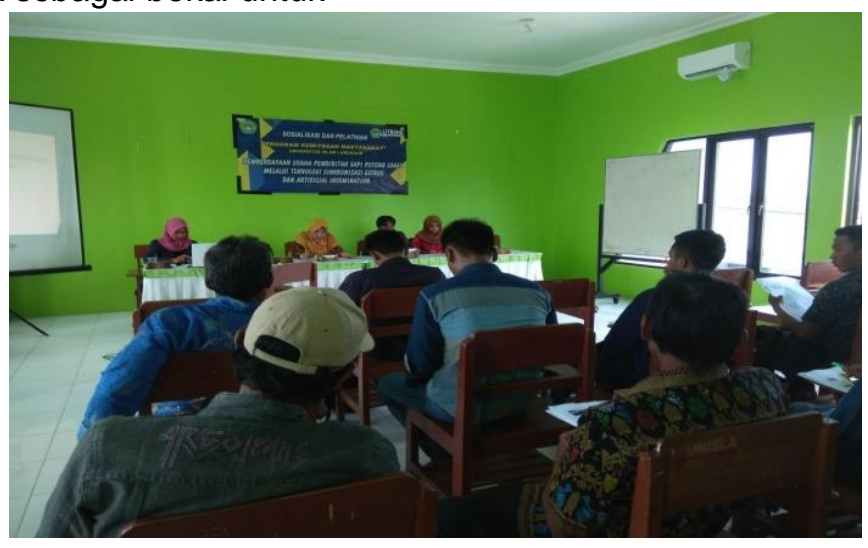

Gambar 2. Kegiatan Penyuluhan I

Sebelum dilakukan penyuluhan, peserta diajak untuk mengerjakan soal pretest. Hasil pre-test menunjukkan bahwa nilai rata-rata yang dicapai peserta rata-rata sebesar 42,5. Nilai tersebut termasuk nilai rendah yang menunjukkan bahwa tingkat pengetahuan peserta terhadap deteksi birahi, sinkronisasi birahi, inseminasi buatan dan recording masih sangat rendah.

Akhir kegiatan penyuluhan diadakan post-test untuk mengetahui seberapa paham terhadap ilmu yang sudah diberikan pada waktu penyuluhan. Hasil post-test menunjukkan nilai rata-rata 74,5 yang termasuk nilai yang cukup. Nilai tersebut lebih baik daripada nilai pre-test sebelumnya. Hal ini karena pada post-test, peserta sudah mendapatkan pengetahuan dari penyuluhan tersebut sehingga dapat menjawab pertanyaan.

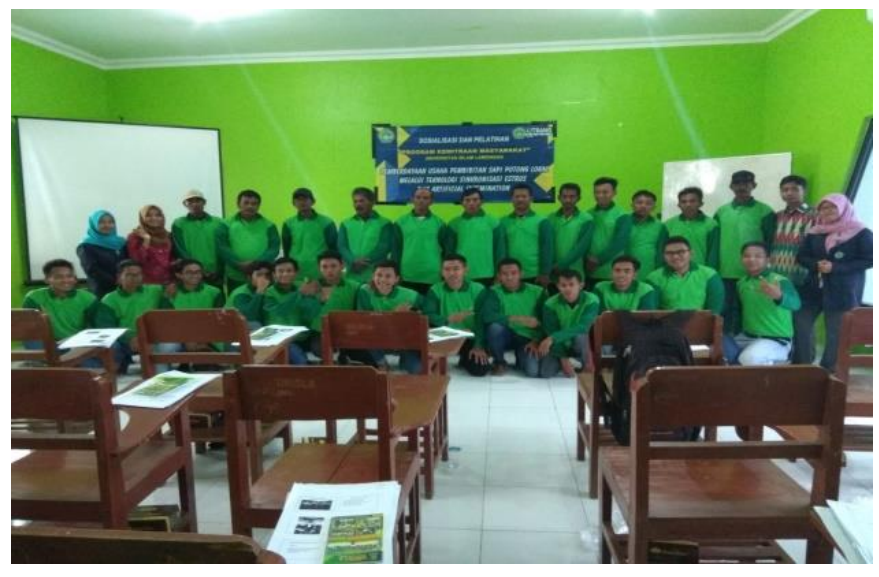

Gambar 3. Kegiatan Penyuluhan II

Kegiatan selanjutnya setelah penyuluhan adalah pelatihan teknik sinkronisasi birahi. Sinkronisasi birahi yang dilakukan adalah dengan metode penyuntikan prostaglandin PGF 2 alpha. Hal ini sesuai dengan
Toelihere dkk., (1990) yang menyatakan bahwa efektivitas preparat PGF2 $\alpha$ terbukti dapat menimbulkan respon estrus sebesar $92,3 \%$ pada sapi Bali 


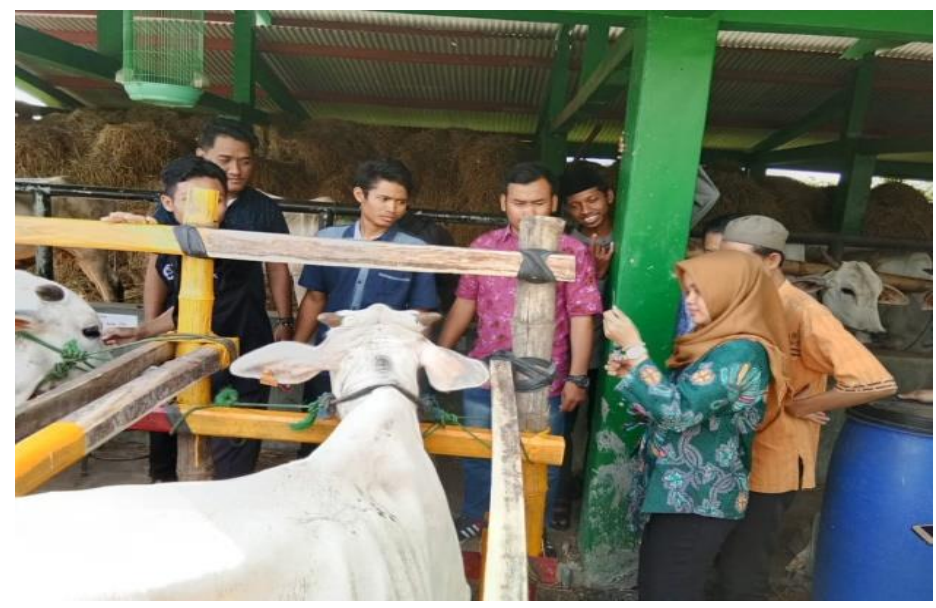

Gambar 4. Pelatihan Teknik Sinkronisasi Birahi

Hasil kegiatan sinkronisasi birahi mendapatkan sapi birahi dengan tanda-tanda vulva berwarna merah, bengkak, hangat dan mengeluarkan lendir berwarna transparan dengan konsistensi kental seperti pada gambar 6.5. Setelah penyuntikan PGF 2 alpha kedua pada waktu kegiatan sinkronisasi, tiga hari kemudian pada sapi tersebut dilakukan IB.

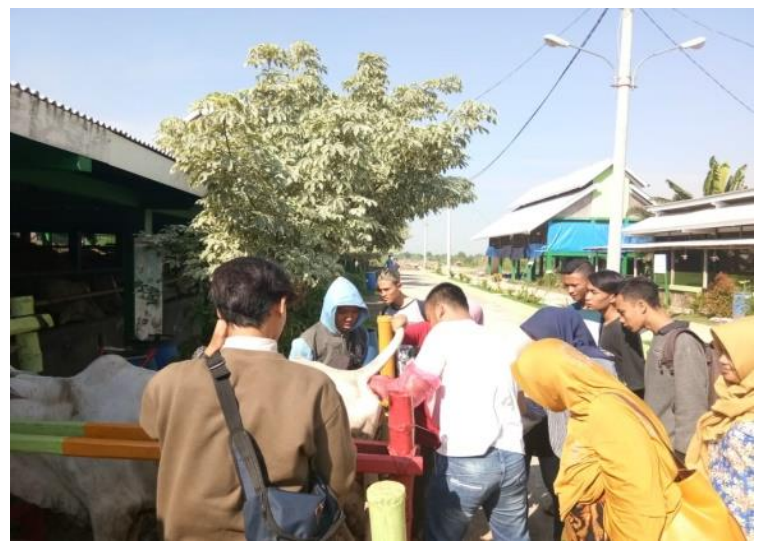

\section{Gambar 5. Pelaksanaan Inseminasi Buatan}

Hasil Inseminasi Buatan dapat dilihat dengan cara pemeriksaan kebuntingan (PKB) yaitu minimal 2 bulan setelah dilakukan IB apakah sapi bunting atau tidak. Hasil PKB pada sapi tersebut kemudian dapat dihitung Service per Conception $(\mathrm{S} / \mathrm{C})$ atau kawin perkebuntingan yaitu jumlah perkawinan sampai seekor induk menjadi bunting. S/C pada pelatihan IB ini adalah 1,5 Angka tersebut menunjukkan nilai S/C yang baik. Hal ini sesuai dengan Toelihere (1981) yang menyatakan bahwa $\mathrm{S} / \mathrm{C}$ yang baik adalah 1,6 sampai 2,0 kali.Nilai $S / C$ menunjukkan tingkat kesuburan ternak, Semakin rendah nilai $\mathrm{S} / \mathrm{C}$ pada ternak maka semakin baik tingkat kesuburan ternak tersebut. Angka S/C jika berada dibawah angka 2 yang berarti sapi masih dapat beranak satu tahun sekali, apabila nilai S/C berada pada angka diatas 2 akan menyebabkan jarak beranak yang tidak ideal dan menunjukkan reproduksi sapi tersebut kurang efisien, yang membuat jarak beranak menjadi lama, sehingga dapat merugikan peternak karena harus mengeluarkan biaya IB lagi dan pemberian pakan selama masa gagal bunting.

Faktor yang mempengaruhi nilai S/C adalah Peternak, Umur Induk, Pakan, Ketepatan IB, Petugas Inseminator, Kualitas straw (sperma sapi), Gangguan reproduksi sapi (Iswoyo dan Widyaningrum, 2008).

\section{KESIMPULAN}

Kegiatan penyuluhan, penyediaan sarana, pelatihan dan manajemen pengelolahan kegiatan di Kelompok Pembibitan Sapi Potong "Berkah" dan kelompok studi IB berjalan cukup baik. Dan selama kegiatan kelompok ternak aktif dalam pelaksanaan dan berperan aktif.

\section{UCAPAN TERIMA KASIH}

Terima kasih sebesar besarnya kami sampaikan kepada DRPM Kementerian Riset, Teknologi dan Pendidikan Tinggi $R I$ atas didanainya Program Kemitraan Masyarakat (PKM) Tahun 2018. Juga kepada Litbang Pemas 
dan Pimpinan Universitas Islam Lamongan atas dukungan dan fasilitas yang diberikan selama proses pelaksanaan hingga pelaporan.

\section{REFERENSI}

Adikara, R.T.S., 1992 . Akupunktur Veteriner. Fakultas Kedokteran Hewan-Universitas Airlangga. Surabaya.

Caprifarmindo Labs., 2015. Capriglandin Inj. Hormon PGF2a Injeksi. PT. Caprifarmindo Labs. Bandung.

Disnak Jatim, 2012. Data Ternak sapi Propinsi Jawa Timur. Dinas Peternakan Propinsi Jawa Timur. Surabaya.

Ditjennak, 2012. Pedoman Optimalisasi Inseminasi Buatan (IB) tahun 2012. Direktorat Jenderal Peternakan dan Kesehatan Hewan. Kementerian Pertanian. Jakarta.

Dwi, L dan Leondro, H. 2014. Inseminasi Buatan. Bahan ajar. Unikama

Guntoro, S., N.Y.M. Suyasa, I.A.P. Parwati, dan M.R. Yasa, 1999. Instalasi Penelitian dan Pengkajian Teknologi Pertanian. Seminar Nasional Peternakan dan Veteriner. Denpasar.

Iswoyo dan Widyaningrum P. 2008. Performance reproduksi sapi peranakan simental (PSM). Hasil Inseminasi Buatan di Kabupaten Sukoharjo Jawa tengah. Jurnal IImiah IImu Peternakan.

Kartasudjana R., 2001. Teknik Inseminasi Buatan pada Ternak. Modul Program Pengembangan Keahlian Budidaya Ternak. Jakarta.

Parwati, I. A. P., 2003. Pendapatan dan FaktorFaktor Yang Mempengaruhi Produksi
Usaha Ternak Sapi. Balai Pengkajian Teknologi Pertanian. Bali

Said, S., B. Tappa, M. Gunawan, C. Arman. 2012. Conception rates of bali cattle after oestrus synchronization with PGF2a and artificial inseminaton using frozenthawed sexed semen. International Conference on Biotecnology. Bogor, Indonesia.

Saili Takdir, La Ode Baa, La Ode Arsad Sani, Syam Rahadi, I Wayam Sura dan Febiang Lopulalan, 2016. Sinkronisasi Estrus dan Inseminasi Buatan Menggunakan Semen Cair Hasil Sexing pada Sapi Bali Induk Yang Dipelihara dengan Sistem yang Berbeda. Fakultas Peternakan Universitas Halu Oleo.UPTD Peternakan,Dinas Pertanian dan Peternakan Sulawesi Tenggara. JURNAL ILMU TERNAK VOL.16, NO.2Sekretariat Desa, 2016. Data Monografi. Desa Jetis. Kecamatan Lamongan. Kabupaten Lamongan.

Toelihere, M.R. 1981. Fisiologi Reproduksi Pada Ternak. Penerbit Angkasa. Bandung.

Toelihere, M.R., I.G.Ng. Jelantik dan P. Kune. 1990. Perbandingan performans produksi sapi Bali dan hasil persilangannya dengan Frisian Holstein di Besipae, Timor Tengah Selatan. Laporan Penelitian Fapet Undana, Kupang.

Wijoseno, S.R., L.G.S. Astiti, T. Panjaitan, A. Muzani dan N. Agustini, 2009. Beternak sapi Intensif. Balai Pengkajian Teknologi Pertanian. Departemen Pertanian. Jakarta.

Yusuf, M., 2012. Buku Ajar IImu Reproduksi Ternak. Jurusan Produksi Ternak. Fakultas Peternakan. Universitas Hasanudin. Makasar. 